\title{
EFFECT OF FORWARDER LOAD SIZE AND NUMBER OF PASSES ON FORMATION OF RUTS IN MAIN FELLING AREAS ON PEAT SOILS (MYRTILLOSA TURF. MEL.) IN LATVIA
}

\author{
Agris Zimelis ${ }^{1}$, Linards Sisenis ${ }^{2}$, Ziedonis Sarmulis ${ }^{2}$ \\ ${ }^{1}$ Latvian State Forest Research Institute "Silava", Latvia; \\ ${ }^{2}$ Latvia University of Life Sciences and Technologies, Latvia \\ agris.zimelis@silava.lv
}

\begin{abstract}
In daily logging practice, there are many cases, when it is not possible to choose the right forwarder type for the working conditions in the felling area and the amount of timber transported. Then consequences are unacceptable: too deep ruts made by the wheels of the forwarder or complete impossibility to use the forwarder as a timber transport vehicle. That is a problem difficult to solve, because the amount of previous research is not sufficient to create a universal and practically available method to obtain credible characteristic of ground bearing capacity. To determine the effect of the timber forwarder on peat soil by various methods, depending on its payload utilization and the amount of branches used to reinforce the road, the observation method takes place in the felling area purposely prepared for such research. Measurements of soil resistance and depth of the ruts in the study site with the amount $50 \mathrm{~kg} \cdot \mathrm{m}^{-2}$ of logging residues for the strengthening mat on technological strip show that the forwarder movement is possible. To predict the possibility of round timber primary transport by a forwarder under production conditions, it is necessary to evaluate the soil shear resistance, as a positive correlation between this parameter, and the depth of the ruts in the given study.
\end{abstract}

Keywords: logging, forwarder, peat soil, ruts.

\section{Introduction}

The determinants of rut formation caused by the forest machine are mentioned in several publications [1-2]. Information obtained from a closer examination of the process of formation of the ruts is also available [3-5]. Separate research works are devoted to ruts pressed into soil above the peat layer [6], or in mineral soil [7-8]. Vast number of different conditions influences forwarder rut formation, and this is a reason for the large diversity of their cross section profiles [9].

In evaluating the forest machine impact on the forest soil as a clear indication of soil damage degree, the ruts pressed into ground surface by wheels (wheel tracks, caterpillar tracks) [10-13], and their measurements [15-16] are used. Nowadays, trials of innovative methods are often used to determine the parameters of ruts [17-18]. The total negative effects of undesirable risks depend on their incidence [12; 19]. Mathematical modelling methods are also used to predict the soil damage risks caused by forest machine impact [20-21]. Information on soil compaction beneath ruts can be found in several studies [22-24].

Since the introduction of mechanized primary transport of timber using tractor machinery in logging, the question of the terrain overcoming capability of this machinery to various forest soils has become a pressing issue. One of the first studies on soil bearing capacity was published in 1959 [31]. First, the physical properties of the forest soil were analysed. Different values of forest soils were already published in 1961. Part of the values characterizing forest soils in connection with the project theme is presented below (the project only analyses forest soils belonging to the peat soil group).

An external load, such as the wheel of a logging machine, causes both compression and displacement of soil along the lateral sides of the wheel, as well as elastic bending of it. In the literature on soil mechanical properties [32], it is noted that the larger the total contact area of the tires, the less the soil load plot is affected at the deeper layers of the soil. Studies at the Karelian University (2010-2015) have shown that in order to improve the bearing capacity of forwarding roads, it is necessary to lay logging residues of $0.02 \mathrm{~m}^{3} \mathrm{~m}^{-2}-0.06 \mathrm{~m}^{3} \mathrm{~m}^{-2}$ on peat soil, and thus ensure for the forest machine sufficient terrain overcoming [33].

The available amount of logging residues per one $\mathrm{m}^{3}$ of stem wood: $50-70 \mathrm{~kg}$ in spruce stand, 80$100 \mathrm{~kg}$ in pine stand, 90-110 kg in birch stand, and 110-140 kg in aspen stand. Depending on the season, the logging technology and other circumstances, 50-70\% of the quantities just mentioned can be considered as actually obtainable [34]. 
Because of the investigations of forest machine use, the topic of the formation of ruts is widely reflected in the research program of the St. Petersburg Forestry University. As a result, there are two dissertations (defended in 2013 and 2014) related to teh research on the creation of forest soil ruts, made during the crawler tractor operation [35]. Historically great attention is paid to the soil bearing capacity, but the specific novelty is the analysis of the forest soil bearing capacity index. The focus of the above-mentioned works is on the bearing capacity of forest soil above mineral ground with different moisture content. Changes in the physical-mechanical properties of forest soil in the risk area of the running gear and mathematical models of these changes were analysed and compared with the penetration rates obtained in practice.

However, these studies do not assess the dynamics and physical-mechanical properties of running gear ruts formation on topsoil above the thick layer of peat. Kiselov D.S in his work reviews the changes of physical-mechanical properties of plastic forest soils in the running gear impact risk area without any felling residue mat [36]. In the works mentioned there are calculations of soil deformation developed by the wheel running part, and the wheel-crawler tandem on mineral soils is proposed.

At the Belarusian State Technological University, A.S. Fedorencik etc. proposed a mathematical model for analysing the formation of ruts in logging strip-roads strengthened with tree felling residues [37]. The use of this model makes it possible to determine the impact of loads caused by the rolling of wheels and wheel tracks on forest soil. Depending on the plasticity and bearing capacity of the forest soil, an increase in the depth of the ruts can be determined after each logging tractor trip along the strengthened strip-road. However, the article does not provide information on the reaction of peat soils to the impact of the running gear, and there is a note that this methodology is not tested on peat soils.

\section{Materials and methods}

Logging operations at the felling area designated for rut formation observations, including primary transport of round timber to the upper landing, were going on until 07.10.2019. There were left approximately $15 \mathrm{~m}^{3}$ of spruce pulpwood at the upper landing needed for the planed experimental studies.

In the felling area, between the 3rd, 4th and 5th strip roads, 8 sample plots has been arranged. Sample plots along the forwarder experimental route (see Fig. 1) are located in half-strips between strip-roads 3 and 4 and between strip-roads 4 and 5 . The length of each plot is $30 \mathrm{~m}$; the figure (see Fig. 1) shows their arrangement. For the sake of strengthening, a special spruce branch mat on the strip-road surface has been created manually in every sample plot (see Fig. 1). To get observation data for control comparisons, approx. $20 \mathrm{~m}$ long breaks without any strip-road surface strengthening mat have been left between the sample plots. The forwarder experimental route arrangement in the sample plots should be so that they do not contain tree stumps, dead wood pieces, etc. obstacles that could impede the forwarder's smooth movement.

To determine the amount of spruce branches needed for the technological strip-road strengthening, the mass method is used. At first, it is necessary to obtain the mass of a single branch supposed as the strengthening material for the strip-road mat. The mass is determined by using a tripod with scales and a hook attached to allow the weighing of a single branch. The diameter of the branch is measured at the point of its cutting, i.e. at the connection point with the tree trunk. All branches make 5 groups according to their average diameter. In the 1st group there are branches up to $2 \mathrm{~cm}$, in the 2 nd group -2.1 to $3.0 \mathrm{~cm}$, in the $3 \mathrm{rd}$ group $->3 \mathrm{~cm}$, in the 4th group - treetops of a diameter under $3 \mathrm{~cm}$, and in the 5th group - treetops of a diameter $3 \mathrm{~cm}$ or over. The length of a branch has a minimum limit equal to the width of the forwarder tire $(40 \mathrm{~cm})$. The number of branches per a sample plot depends on three determinants (see exp. 1).

$$
Z_{s k}=\frac{P L \times A}{z_{m}},
$$

where $Z_{s k}$ - number of branches, pcs;

$P L$ - covered area in the plot, $\mathrm{m}^{2}$;

$A$ - mass of branches for the mat on strip-roads, $\mathrm{kg} \cdot \mathrm{m}^{-2}$;

$Z_{m}$ - mass of a single branch, $\mathrm{kg}$. 
(3)

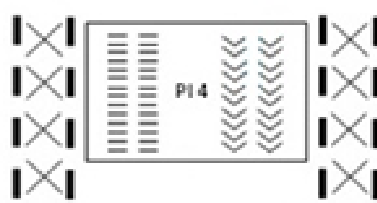

$1 \times \mathbf{I} \equiv \equiv \approx$

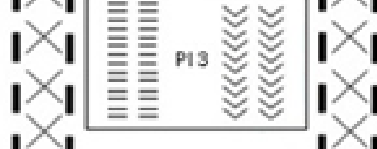

$1 \times$
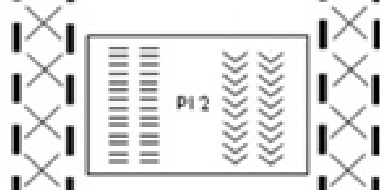

1

1 I

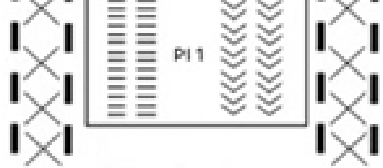

(4)

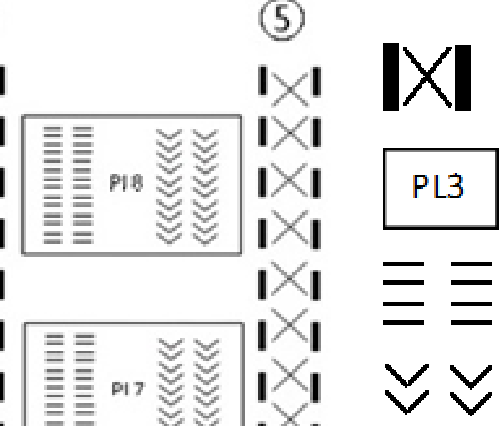

strip road

sample plot boundaries with sequence numb er

strip-road with branch mat $20-30 \mathrm{~kg} \cdot \mathrm{m}^{-2}$

strip-road with branch mat $40-50 \mathrm{~kg} \cdot \mathrm{m}^{-2}$

Fig. 1. Part of the felling area where the loaded forwarder's experimental route took place

The soil shear resistance measuring device uses a NORBAR TORQUE (Model: NorTronic 330) torque wrench, which provides a measurement accuracy of $\pm 3 \%$, according to the factory certificate (ISO 6789-2: 2017). The measuring range is up to $400 \mathrm{Nm}$. The device requires self-calibration, which takes up to 20 seconds before making measurements. As a further step, the device should be set to $30 \mathrm{Nm}$ as the starting value, as well as the turning angle at which the measurement is recorded. The angle is set equal to $45^{\circ}(T=30+45)$.

Measurements should be made on the strip-road branch mat, and in control areas without branches, to obtain data to assess the effect of the branch mat on the soil bearing capacity. A conversion factor of 0.496 , which describes the number of bars used in the measurements and their location on the device, is used to calculate the soil shear resistance. The shear resistance is calculated from the equation (see exp. 2).

$$
q=0.496 \times J(\mathrm{Nm}) .
$$

Trials began with the arrival of logging equipment at the end of September and the start of timber harvesting technological operations. There has been practically unforeseen interruption of almost a month after the completion of the full-mechanized logging work until the start of the study in early November. The study initially aimed to determine the effect of the forwarder on the soil by various methods, depending on the payload utilization and the amount of branches used to reinforce the road.

Data processing is performed in RStudio software, sample conformance to normal distribution is determined by the Shapiro-Wilk Normality test. One-factor ANOVA analysis of variance is used to determine whether the shear resistance varies significantly with the amount of branches placed in the technological strip-road.

\section{Results and discussion}

The reinforcement of the technological strip-road is going on manually according to the planned scheme. In accordance with the methodology described above to determine the individual weight of the branches, the required number of them found in the mass calculation has to be corresponding to the necessary amount for the strip-road strengthening process.

Totally 221 branches are weighed, which are divided into 5 groups. Group 1 accounts for $25 \%$ of total volume, group 2 - for $41 \%$, group 3 - for $25 \%$, group 4 - for $5 \%$ and group 5 - for $4 \%$ of total volume. The resulting percentage corresponds to the total of a given group. For example, groups 4 and 
5 consist of treetops that make a small part in total volume, because they relate to the total number of trees in the stand. The Quartile method reflects the total weight of the branches.

Based on the results obtained for the average branch weight, a combination of different branch diameters is the most appropriate solution to ensure the intended strip-road mat durability: 40-50 $\mathrm{kg} \cdot \mathrm{m}^{-2}$ in the first variant and $20 \mathrm{~kg} \cdot \mathrm{m}^{-2}$ in the second variant. The total covered area by one method is $960 \mathrm{~m}^{2}$. Depending on the planned amount of branches per one $\mathrm{m}^{2}$, the required number for total area is from 1012 pieces up to 21792 pieces (Table1).

Table1

Distribution of volume of branch material required by groups

\begin{tabular}{|c|c|c|c|c|c|}
\hline \multirow{2}{*}{$\begin{array}{c}\text { Mass required, } \\
\mathbf{k g} \cdot \mathbf{m}^{-2}\end{array}$} & \multicolumn{5}{|c|}{ Number of branches required, pieces } \\
\hline & 1.group & 2. group & 3. group & 4. group & 5. group \\
\hline 40 & 21792 & 13755 & 10085 & 3952 & 2023 \\
\hline 50 & 27240 & 17193 & 12606 & 4940 & 2529 \\
\hline 20 & 10896 & 6877 & 5042 & 1976 & 1012 \\
\hline
\end{tabular}

Shear resistance measurements in the forest industry characterize different driving conditions, justifying their classification, as well as developing recommendations for choosing the most appropriate forest harvesting technique for use in machine operations. In general, the shear resistance has to be analysed in a complex way, since the data obtained are affected by the tree roots (their nets), felling residues and the undergrowth left after it has been cut, which generally affects the soil overall resistance against pressure [38].

In verification of the shear resistance data compliance with normal distribution it has been found that $p=0.32$ in the technological strip with the branch mat, and in the technological strip without any strengthening $-p=0.86$. This confirms that the data sample corresponds to the normal distribution, since the $\mathrm{p}$ value in both cases is numerically greater than 0.05 .

The measurements carried out in the study show the highest shear resistance in those technological strips without the ruts. In the ' 0 ' group (no ruts caused by the forwarder), the shear resistance reading is $127 \pm 55 \mathrm{kPa}$. In contrast, according to the current regulatory framework, where only cavities pressed into ground by the running gear are deeper than $20 \mathrm{~cm}$, are considered to be a rut (group 4 in the study), consequently, formation of ruts could be expected starting with a numerical decrease in the shear resistance only below $45 \pm 10 \mathrm{kPa}$ (Fig. 2).

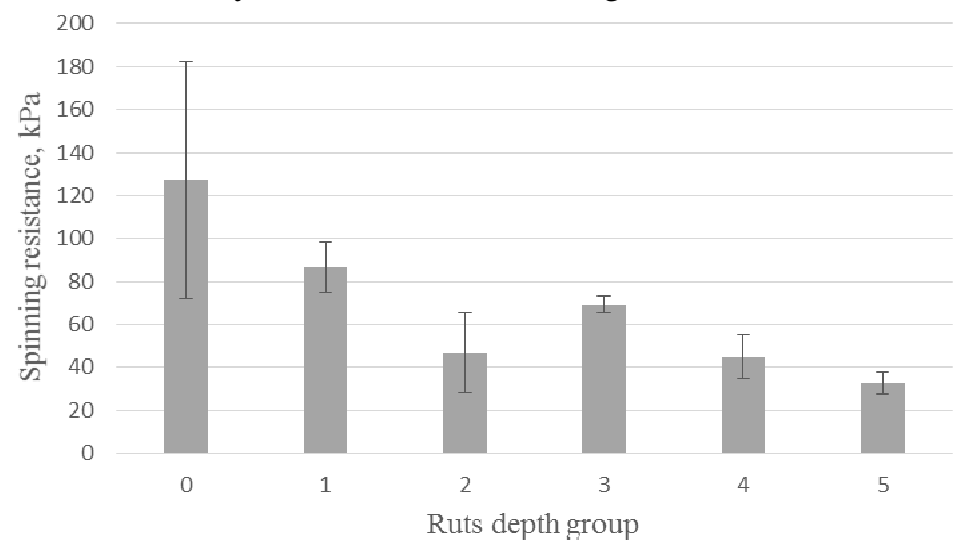

Fig. 2. Shear resistance in the distribution of risk groups

Comparison of the shear resistance values between the technological strips shows that the branch mat cover has a statistically significant effect on the technical feasibility $(\mathrm{p}=0.01)$. The study found that the use of properly arranged branch mats could successfully secure the planned primary transport of round timber to the upper landing site. It is possible, as the pressure on the soil, exerted by the forwarding vehicle, is lower than the soil resistance (Fig. 3).

Measurements of soil resistance and depth of the ruts in the study site with the amount $50 \mathrm{~kg} \cdot \mathrm{m}^{-2}$ of logging residues for the technological strip strengthening mat show that forwarder movement is possible. 


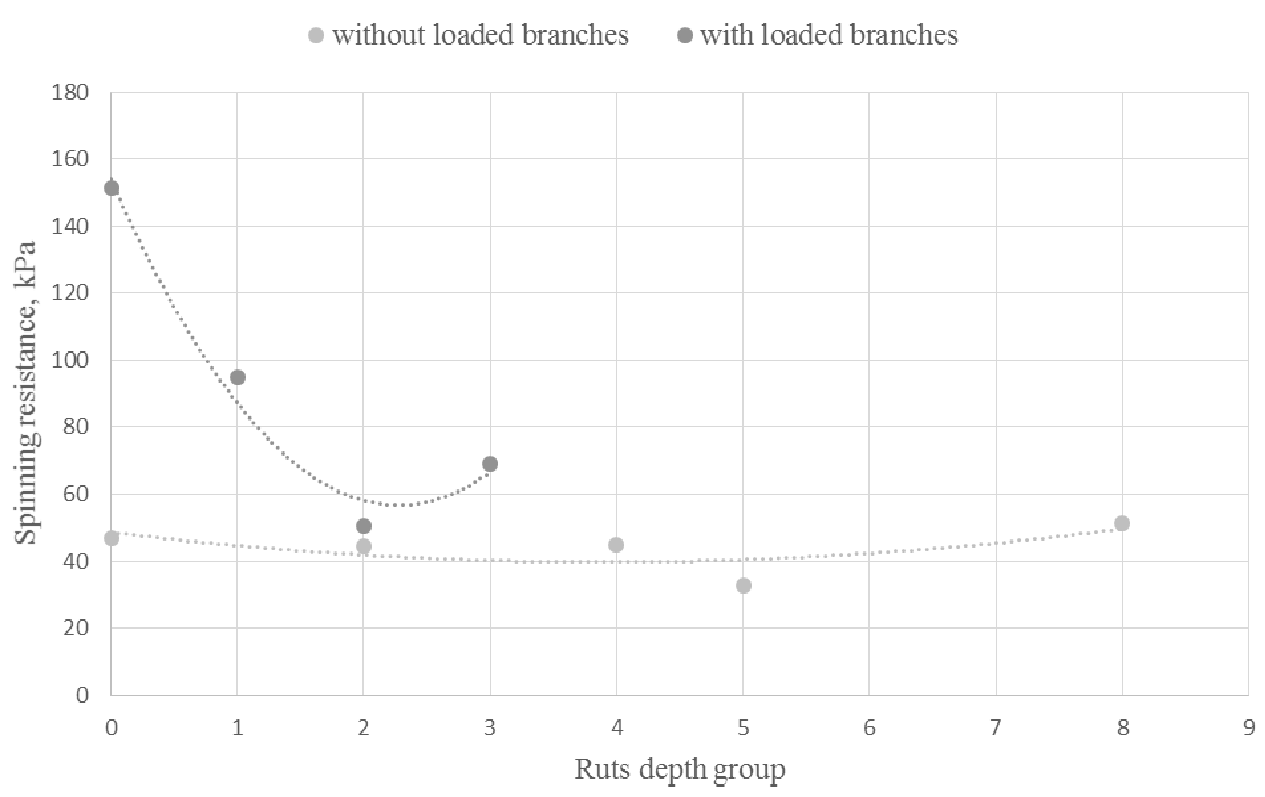

Fig. 3. Shear resistance depending on the technological strip strengthening

Improvements in terrain overcoming capability of a forwarding vehicle that could be explained with a strengthening mat on the technological strip result in an average of $67 \%$ increase in the soil resistance compared to the control area, i.e. at the technological strip without any strengthening. During the experimental trials, the timber forwarder pressure onto the ground surface equals $0.35 \mathrm{MPa}$ (fully loaded) and $0.33 \mathrm{MPa}$ (half loaded).

The obtained data show a close relationship between the soil resistance and the transport vehicle ground pressure. Few similar soil-related studies in Latvia use shear resistance measurements as input data. At the global level, there are relatively more such studies in Sweden. In general, it can be concluded that the shear resistance and rut depth indicators can be used in practice to characterize the driving conditions at a felling area and thus avoid the downtime of the machinery in case of its stuck into ground. The equation obtained in the study $\left(y=2.8156 x^{2}-30.88 x+119.16\right)$ is useful for determining the potential depth of the ruts depending on the soil shear resistance index.

\section{Conclusions}

1. Driving the vehicle for timber forwarding along the technological strip without the strengthening mat on it is difficult. In some places, it is not possible even once.

2. Using support tracks for all running gear tandem equipment and with the strengthening of the technological strip by a branch mat in the felling area ensures successful forwarding of timber with the forwarder.

3. In order to predict the possibility of round timber forwarding under production conditions, it is necessary to evaluate the soil shear resistance, as a close correlation between this parameter and the depth of the ruts takes place in the given study.

\section{Acknowledgements}

Acquiring the field measurement data is within the scope of the Forest Development fund project No. 080719/S70 "Impact of number and size of passing forwarder loads on formation of ruts in clearfelling sites with organic soils". Data synthesis and evaluation of results are within the scope of the Forest sector Competence Centre project No. 1.2.1.1/18/A/004 "Evaluation of alternative harvesting solutions in non-conventional felling types".

\section{References}

[1] Han H.-S., Page-Dumroese D., Han S.-K., Tirocke J. Effects of slash, machine passes, and soil moisture on penetration resistance in a cut-to-length harvesting. International Journal of Forest Engineering. 17(2), 2016. pp.11-24. 
[2] Mohtashami S., Eliasson L., Jansson G., Sonesson J. Influence of soil type, cartographic depth-towater, road reinforcement and traffic intensity on rut formation in logging operations: a survey study in Sweden. Silva Fennica, 2017, vol. 51, no 5.

[3] Cambi M., Giannetti F., Bottalico F., Travaglini D., Nordfjell T., Chirici G., Marchi E. Estimating machine impact on strip roads via close-range photogrammetry and soil parameters: a case study in central Italy. iForest 11, 2017. pp. 148-154.

[4] Edlund J. Harvesting in the Boreal Forest on Soft Ground: Ways to reduce ground damage. Umeå, 2012. $46 \mathrm{pp}$.

[5] Ismoilov A., Sellgren U., Andersson K., Löfgren B. A comparison of novel chassis suspended machines for sustainable forestry, 2015.

[6] Uusitalo J., Salomäki M., Ala-Ilomäki J. The Effect of Wider Logging Trails on Rut Formations in the Harvesting of Peatland Forests. Croatian Journal of Forest Engineering, Vol. 36, no 1, 2015. pp. $125-130$.

[7] Eliasson L., Wästerlund I. Effects of slash reinforcement of strip roads on rutting and soil compaction on a moist fine-grained soil. Forest Ecology and Management. Vol. 252, issue 1 - 3, 2007. pp. 118-123.

[8] Sirén M., Salmivaara A., Ala-Ilomäki J., Launiainen S., Lindeman H, Uusitalo J. Predicting forwarder rut formation on fine-grained mineral soils. Scandinavian Journal of Forest Research. Vol. 34, issue 2, 2019. pp. 145-154.

[9] Labelle E.R., Poltorak B.J., Jaeger D. Soil displacement during ground-based mechanized forest operations using mixed-wood brush mats. (2018) Soil and Tillage Research. 179, February 2018, pp. $96-104$.

[10] Bygdén G., Eliasson L., Wästerlund I. Rut depth, soil compaction and rolling resistance when using bogie tracks. Journal of Terramechanics. Vol. 40, issue 3, July 2003, pp. 179-190.

[11] Cvetkova R., Noviks G. Meža izstrādes procesu ietekmes uz meža ekosistēmu izpēte un optimālas tehnologijas pamatojums. (Study of the Impact of Forest Development Processes on Forest Ecosystems and Justification of Optimal Technology). Rēzeknes tehnologiju akadēmija. 20. starptautiskā studentu zinātniski praktiskā konference. Cilvēks. Vide. Tehnologiijas. 2016, (In Latvian).

[12] Lazdiņš A., Zimelis A., Spalva G. ProSilva 15-4ST pievedējtraktora degvielas patēriņa un kravnesības novērtējums krājas kopšanas cirtēs.( Evaluation of ProSilva 15-4ST forwarder fuel consumption and load capacity in thinnings) İsais zinojums Nr 2015-18, 2015. 3 pp. (In Latvian).

[13] Pužuls K., Štāls T., Zimelis A., Lazdiņš A. Preliminary conclusions on application of ultrasonic sensors in evaluation of distribution and depth of ruts in forest thinning. 2018. 9 pp.

[14] Saarilahti M., Anttila T. Rut depth model for timber transport on moraine soils. Proceedings of the 9th International Conference of International Society for Terrain-Vehicle Systems, 14th - 17th September 1999, Munich, Germany, pp. 29-37.

[15] Cambi M., Giannetti F., Bottalico F., Travaglini D., Nordfjell T., Chirici G., Marchi E. Estimating machine impact on strip roads via close-range photogrammetry and soil parameters: a case study in central Italy. iForest 11, 2017. pp. 148-154.

[16]Poikela A. Harvesting Wood from Spruce Swamp Stand During Summer. Soil / machine workshop, Finland, 23.11.2011, Hyytiälä 21 pp.

[17]Poršinsky T., Pentek T., Bosner A., Stankič I. Ecoefficient Timber Forwarding on Lowland Soft Soils. In: Global Perspectives on Sustainable Forest Management. GIS for operative support. InTech, 2012, pp. $275-288$.

[18] Salmivaara A., Miettinen M., Finér L., Launiainen, S., Korpunen H., Tuominen S. Wheel rut measurements by forest machine-mounted LiDAR sensors - accuracy and potential for operational applications. International Journal of Forest Engineering, 2018.

[19] Owende P.M.O., Lyons J., Ward S.M. Operations Protocol for Eco-efficient Wood Harvesting on Sensitive Sites. ECOWOOD Partnership, 2002. 74 pp.

[20] Carlsson D., Rönnqvist M., Westerlund A. Extraction of logs in forestry using operations research techniques. Proceedings of the 32nd Annual Hawaii International Conference, 1999.

[21] Palander T., Kärhä K. Development of Computational Model to Predict Rut Formation using GIS for Planning of Wood Harvesting on Drained Peat Lands. International Journal of Advanced Engineering. Vol-2, Issue-12, Dec- 2016, pp. 2040 - 2057. 
[22] Ampoorter E., Van Nevel L., De Vos B., Hermy M., Verheyen K. Assessing the effects of initial soil characteristics, machine mass and traffic intensity on forest soil compaction. Forest Ecology and Management. Vol. 260, issue 10, 2010. 15 October 2.

[23] Cambi M., Certini G., Fabiano F., Foderi C., Laschi A., Picchio R. Impact of wheeled and tracked tractors on soil physical properties in a mixed conifer stand. iForest - Biogeosciences and Forestry, Vol. 9, issue 1, 2015. pp. 89-94.

[24] Gerasimov Y., Katarov, V. Effect of Bogie Track and Slash Reinforcement on Sinkage and Soil Compaction in Soft Terrains. Croatian Journal of Forest Engineering. Vol. 31 No. 1, 2010. pp. 3545.

[25] Hakkila P. Utilization of Residual Forest Biomass. Effects of Residue Removal on Forest Health and Environment. 1989. 568 pp.

[26] McDonald T. P., Seixas F. Effect of Slash on Forwarder Soil Compaction. Journal of Forest Engineering. Vol. 8, 1997 - issue 2, 2013. pp. 15 - 26.

[27] Labelle E.R., Jaeger D. Quantifying the use of brush mats in reducing forwarder peak loads and surface contact pressures. Croatian Journal of Forest Engineering. Vol. 33, no 2, 2120. p. 249274.

[28] Lazdāns V., Epalts E., Kariņš Z., Kāposts V., Liepa J., Blija T., Āboliṇa A., Laiviņa S., Lazdiņa D. Tehnikas ietekme uz augsni. (Impact of the Technique on the Soil) LVMI "Silava". 2004. 63 pp. (In Latvian).

[29] Murphy G., Brownlie R., Kimberley M., Beets P. Impacts of forest harvesting related soil disturbance on end-of-rotation wood quality and quantity in a New Zealand radiata pine forest. Silva Fennica 43(1), 2009. pp. 147-160.

[30] Nugent C., Kanali C., Owende P. O., Nieuwenhuis M., Ward S. Characteristic site disturbance due to harvesting and extraction machinery traffic on sensitive forest sites with peat soils. Forest Ecology and Management. 2003. Vol. 180, issues 1-3, 17.

[31] Бабков В.Ф. Проходимость колёсных машин по грунту. (Terrain wheel vehicles passability). Автотрансиздат, 1959. 208 стр. (In Russian).

[32]Колбас Н.С. Дорожное грунтоведение с основами механики грунтов. (Road Soil Science with Fundamentals of Soil Mechanics) Ленинград, 1987. 46 стр. (In Russian).

[33]Галактионов О. Н., Кузнецов А. В. Исследование взаимосвязи технологической проходимости лесозаготовительных машин с параметрами лесной среды. (The study of the relationship of technological passability of forest machines with forest parameters). Инженерный вестник Дона, 2012. (In Russian).

[34] Ieviņš I., Epalts A. Mūsdienu mežizstrāde un mežaudžu mehāniskie bojājumi, to cēloṇi, bīstamība un samazināšanas iespējas. (Nowadays Logging and Mechanical Damage to Forest Stands, Their Causes, Dangers and Reduction Possibilities) Mežsaimniecība un mežrūpniecība. Referātu krājums, Nr. 6, 1982, pp. 24.-28. (In Latvian).

[35]Лисов В. Ю.\& Язов В. Н., Экспериментальное определение водопроницаемости лесной почвы в зависимости от ее плотности. (Experimental determination of permeability of forest soil depending on its density). Вестник Поволжского государственного технологического университета, 4, (20), 2013. стр. 81 - 90. (In Russian).

[36]Базаров С.М., Григорьев И.В., Киселев Д.С., Никифорова А.И., Иванов А.В. Влияние деформации движителей колесно-гусеничных машин на их проходимость по лесосеке. (Influence of deformation of movers of wheeled-tracked vehicles on their felling area passability). Системы. Методы. Технологии. 2012, № 4 (16) стр. 36-40. (In Russian).

[37]Федоренчик А.С., Макаревич С.С., Протас П.А. Аналитическое исследование колееобразования на трелевочных волоках, укрепленных отходами лесозаготовок. (Analytical Research of Rutting on Skidding Trails Consolidated by Logging Waste) Лесной журнал, 1, 2002, стр. 81 - 90. (In Russian).

[38]Eliasson L.,, Wästerlund I. Effects of slash reinforcement of strip roads on rutting and soil compaction on a moist fine-grained soil. Forest Ecology and Management, 252(1), 2007. pp. 118123. 